\title{
Coping with the Perils of the Sea: The Last Voyage of Vrouw Maria in $1771^{1}$
}

\section{Oscar Gelderblom}

On 5 September 1771 the Dutch ship Vrouw Maria left Amsterdam for St. Petersburg. A month later, in the evening of 3 October, the vessel encountered a heavy storm near Turku ( $\mathrm{Abo}$ ), where it was holed by a rock and began to take on water. The master, Reynoud Lourens, ordered his crew to start pumping. Throughout the night nine men worked to save the craft. By the next morning most of the water was indeed pumped out, but the leak was not stopped. In this hopeless situation Lourens gave the order to abandon ship. The crew sought refuge on a nearby island, where local fishermen found them the next evening. Over the next few days the crew and the local salvage company returned to the vessel every day to try to salvage as much cargo as possible. It was only upon their arrival on 9 October that they discovered that Vrouw Maria had sunk.

Vrouw Maria was one of many merchantmen lost in Finnish waters in the eighteenth century. Unlike most of these ships, this wreck was found almost intact in 1999. This led the Finnish Maritime Museum to investigate it thoroughly to decide whether it should be raised. In this essay the story of Vrouw Maria is told from a Dutch perspective. Building on the work of the Finnish scholar Christian Ahlström, ${ }^{2}$ it reconstructs both the preparations for the vessel's last

'The author would like to thank Ismo Malinen, Joost Jonker, Cor Trompetter, Marten Jan Bok and Marcel van der Beek for their helpful comments and suggestions. He would also like to thank the Directie van Oosterse Handel en Rederijen for funding the present research.

${ }^{2}$ The wreck and partial salvaging of Vrouw Maria have been analysed in considerable detail by C. Ahlström, "Documentary Research on the Baltic. Three Case Studies," International Journal of Nautical Archaeology and Underwater Exploration, VII, No. 1 (1978), 59-70; Ahlström, Sjunkna skepp (Lund, 1979); Ahlström, Looking for Leads. Shipwrecks of the Past Revealed by Contemporary Documents and the Archaeological Record (Helsinki, 1997); Ahlström, "The Russian Empress and the Dutch Kofschip Vrouw Maria,"Nautica Fennica (2000), 13-16; and Ahlström, "The Vrouw Maria of 1771: An Example of Documentary Research," in C.O. Cederlund (ed.), The Marine Archaeology of the Baltic Sea Area (III) Newsletter (2000), 43-49. After the completion of the present text, yet another article on Vrouw Maria was published by A. Verweij, "De

International Journal of Maritime History, Vol. XV, No. 2 (December 2003), 95-115. 
voyage and the actions undertaken by the merchants to recover their losses. ${ }^{3}$ This study not only relates the misfortune of a single ship but also allows an assessment of the efficiency of the eighteenth-century institutions with which Dutch merchants organized the shipment of goods, protected them against the perils of the sea and handled their losses. ${ }^{4}$

Dutch trade with Russia began in the 1580s when Antwerp merchants settled near the convent of St. Michael Archangel at the estuary of the River Dwina in northern Russia. The settlement quickly developed into the port of Archangel, which was to be the home of Dutch merchants for almost 200 years. Exports from Archangel in the early seventeenth century consisted of timber, fur, tallow and occasionally grain. From the 1650 s onwards leather, hemp and ashes were the principal commodities. In exchange, textiles, jewelry, spices, metal wares and all kinds of luxury items were sent to Archangel and from there on to Moscow. The second half of the seventeenth century was the zenith of Dutch trade with Archangel. Once the tsar banned the English Muscovy Company from Archangel in 1649 , the Dutch engrossed about seventy-five percent of all trade. ${ }^{5}$

It was only after 1700 that the Dutch lost their dominance in Russia. In the 1690s the Russian emperor allowed English merchants to return to Archangel. The Muscovy Company initially failed to grasp this opportunity, but when the English parliament decided in 1699 to allow any merchant who paid $£ 5$ to join the company, the English share in the Archangel trade rose quickly; by 1710 more than forty percent of the trade was in the hands of English merchants. The Dutch suffered even more from the foundation of St. Petersburg at the mouth of the River Neva in $1703 .{ }^{6}$ Once the Great Northern War (1700-1721) was over, the

laatste reis van Vrouw Maria. Een geval van zeeschade in 1771," Tijdschrift voor Zeegeschiedenis, XXI, No. 2 (2002), 136-152. In this text Verweij summarizes the contents of many documents that were also consulted for the present reseach. Therefore, references to his text have been added only in those cases where he provides new information or where his interpretation differs from that of the prehsent author.

${ }^{3}$ Ahlström, "Vrouw Maria," 47.

${ }^{4}$ C.A.Davids, "Zekerheidsregelingen in de scheepvaart en het landtransport, 1500-1800," in J. van Gerwen and M.H.D. van Leeuwen (eds.), Studies over zekerheidsarrangementen (Amsterdam, 1998), 183-202.

5J.W. Veluwenkamp, Archangel. Nederlandse ondernemers in Rusland (Amsterdam, 2000), 45 and 107-110.

${ }^{6} \mathrm{~W}$. Kirchner, Commercial Relations between Russia and Europe, 1400-1800: Collected Essays (Bloomington, 1966), 19-20; and J.V.Th. Knoppers, Dutch Trade with Russia from the Time of Peter I to Alexander I: A Quantitative Study in Eighteenth Century 
English were quick to establish themselves as the principal traders in this new Russian gateway. While most Dutch merchants continued to trade with Archangel, the British fetched growing quantities of bar iron, timber, hemp, flax and linen from the new port. By 1770 English merchants organized two-thirds of all exports from St. Petersburg compared with five percent for the Dutch. Moreover, the former outdid the latter in providing Russia with textiles. In the early years of Catherine II's reign imports to St. Petersburg were in the hands of Russian and English merchants (thirty-seven and twenty-five percent, respectively), with the Dutch only a distant third (ten percent). ${ }^{7}$

Even if Dutch trade with St. Petersburg was limited, it did involve leading merchant houses from Amsterdam. Among the thirty-four known freighters of Vrouw Maria were several firms with long-standing business interests in Russia. Lodewijck Hovy, the son of a surgeon in the Russian fleet who had moved from Moscow to Amsterdam, traded with Russia since the 1730s. In 1771 Hovy and his eldest son were among Amsterdam's principal Russian traders. ${ }^{8}$ The merchant house of Raymond and Theodoor de Smeth, founded in 1736, was the first foreign banker of Russia. Between 1769 and 1782 the firm issued seven loans with a total value of seventeen million guilders on behalf of Catherine II. As a reward for his services, Theodoor de Smeth was ennobled by the empress in 1772. ${ }^{9}$ To be sure, the merchants who transported goods in Vrouw Maria were involved in more than simply the Russian trade. The merchant house of George Clifford and Teysset, for example, specialized in trade with France, England and Spain. ${ }^{10}$ The Van der Poll family, operating under the name of Harman van de Poll, was involved in commodity trade, plantations in Surinam, insurance and banking for foreign rulers like the king of Denmark and Norway. ${ }^{11}$

Shipping (3 vols., Montréal, 1976), I, 148.

${ }^{7}$ H.H. Kaplan, Russian Overseas Commerce with Great Britain during the Reign of Catherine II (Philadelphia, 1995), 177-181.

${ }^{8} \mathrm{~J} . \mathrm{H}$. Hovy, “Het leven van de patriot Lodewijk Hovy (1740-1822), zijn rol als vroedschap van Amsterdam gedurende de jaren 1780-1787" Jaarboek Amstelodumum, LXXIX (1987), 126; and I. Schöffer, "De vonnissen in averij grosse van de kamer van assurantie en avarij te Amsterdam in de $18 \mathrm{e}$ eeuw," Economisch-Historisch Jaarboek, XXVI (1956), 102. 798-800.

\footnotetext{
${ }^{9}$ J.E. Elias, De Vroedschap van Amsterdam 1578-1795 (Haarlem, 1903), clx and
}

${ }^{10}$ Ibid., 885 .

${ }^{11}$ Ibid., 752-756. 
The merchants and bankers of Muilman and Sons traded mostly with England and Italy. ${ }^{12}$

Even if the Dutch played a minor role in the Russian trade, Amsterdam maintained regular shipping services with St. Petersburg. On average thirty-five ships sailed annually to the Russian port in the third quarter of the seventeenth century.$^{13}$ For merchants who wanted to charter a ship to carry their goods to St. Petersburg, there was no difficulty finding cargo space. They could approach a notary or broker on the Amsterdam exchange or turn directly to one of the many shipping companies in the city. In fact, several shipping companies employed a broker to keep their accounts, to direct and monitor the master and to negotiate the terms of shipment with both the master and the consigners. ${ }^{14}$ In return the broker was paid a salary and was also allowed to take part in the shipping company and to ship some goods on his own account. ${ }^{15}$ In the case of Vrouw Maria in 1771, the merchants contacted the Amsterdam broker Tamme Ysbrantsz Beth.

Beth was the son of a rich Amsterdam shipbroker. ${ }^{16}$ Born in the 1720 s, he married the daughter of a mastmaker in $1743 .{ }^{17}$ In 1750 Tamme Beth became

${ }^{12}$ Ibid., 866-870.

${ }^{13}$ S. van Brakel, "Statistische en andere gegevens betreffende onzen handel en scheepvaart op Rusland gedurende de $18^{\text {de }}$ eeuw," Bijdragen en Mededeelingen van het Historisch Genootschap, XXXIV (1913), 382-388; and J.V.Th. Knoppers, "De vaart in Europa," in F.J.A. Broeze, J.R. Bruijn and F.S. Gaastra (eds.), Maritieme geschiedenis der Nederlanden, III (Bussum, 1977), 249-251.

${ }^{14}$ I.H. van Eeghen, "De Vos \& Zoon en de Amsterdamse assurantiebezorgers," Jaarboek Amstelodamum, LXXII (1980), 44-62; and S. Hart, "Rederij," in L.M. Akveld, S. Hart and W.J. van Hoboken (eds.), Maritieme Geschiedenis der Nederlanden, II (Bussum, 1977), 111-112.

${ }^{15} \mathrm{Cf}$. an undated (the handwriting suggests the eighteenth century) document in the brokers' guild archives which indicates that, if the other shipowners agree, the City Council did not object to brokers with a share in a ship. Amsterdam City Archives (GAA), $366 / 1042$.

${ }^{16}$ In 1742 Tamme Beth still lived with his father Ussbrantsz Beth. In the income tax of this year (Personele Quotisatie), the father's income was estimated at 2500 guilders. With this income his father belonged to the 2500 richest inhabitants of Amsterdam: W.F.H. Oldewelt, Kohier van de Personeele Quotisatie te Amsterdam over het jaar 1742 (Amsterdam, 1945).

\footnotetext{
${ }^{17}$ Van Eeghen, "De Vos," 113.
} 
a member of Amsterdam's brokers' guild. ${ }^{18}$ Although he was not mentioned among the most prominent brokers in shipping shares in $1756,{ }^{19}$ Beth did become a leading broker in later years. By the time Vrouw Maria sailed to St. Petersburg, he was bookkeeper for at least two, but probably more, companies. ${ }^{20}$ In addition, he organized public sales of ships and shipping shares. ${ }^{21}$ There is little doubt that Tamme Beth was a successful businessman. In 1763 he replaced his house on the Singel, worth 18,000 guilders, with a new new one, called "Fruit of the Sea" (Zeevrucht) ${ }^{22} \mathrm{He}$ must also have owned a yacht, since he was regularly appointed commissioner of the city's old marina between 1765 and $1782 .^{23}$

Tamme Beth managed the affairs of Vrouw Maria from at least 1766. In August of that year he sold the ship, lying on the wharf at Kattenburg, at a public auction to the Amsterdam merchant and cashier Coenraad Vissering. ${ }^{24}$ The new owner immediately took on Beth as bookkeeper and co-owner (medereder) of the

\section{${ }^{18}$ GAA $1191 / 114$.}

${ }^{19}$ Ibid., 1191/133.

${ }^{20}$ Ibid., 5036/8, 21 March and 19 April 1770. The tax registers reveal that in 1770 Beth was involved in the purchase and sale of four ships and five shipping shares. GAA 5047/368, fol. 20v, 41v-42 and 46-46v; 5047/369, fol. 3v, 4v, 14v, 29, 37 and 46; Cf. also the regular appearance of Tamme Beth Isbrantsz in the records of the Commissionaries of Sea Affairs in the 1770s in GAA 5061/2613, fol. 83, 217 (247), 250, 261 and 264.

${ }^{21}$ For the sales of ships and shipping shares in 1766, see GAA 5071/29.

${ }^{22}$ Van Eeghen, "De Vos," 113.

${ }^{23} \mathrm{G}$. Backer, "Lijst van de namen der Overlieden van de oude jachthaven," Jaarboek Amstelodamum, XI (1913), 170-171.

${ }^{24}$ GAA, Notarial Archives (NA) 12043/483, September 1766; and Vissering: "Laatste reis," 136. Finnish maritime archeologists have expressed doubts as to whether the kofschip sold in 1766 was indeed the one that sank in the Finnish Skerries. Their exploration of the wreck suggests that it had features more typical of a snauschip than of a kofschip. Moreover, Vrouw Maria is mentioned as a snauschip in Swedish documents relating to the shipwreck; M. Laitinen, "Vrouw Maria -hylky ja 1700-luvun hollantilaiset purjealustyypit kirjallisissa lähteissä," Suomen keskiajan arkeologian seura, IV (2000). It seems unlikely, however, that Beth and Lourens, both explicitly mentioned in the deed of sale, were also involved in another ship of the same name unless it was replaced by an entirely new vessel in a following year - but there is no evidence for this. 
vessel. ${ }^{25}$ While the broker probably did most of the paperwork, the master was responsible for the ship, crew and cargo ${ }^{26}$ Reynoud Lourens, a Danish immigrant in Amsterdam, ${ }^{27}$ was already mentioned as master in the sales documents and subsequently appeared in many records relating to Vrouw Maria. In Amsterdam Lourens co-operated with Beth to prepare its sailings. The master signed at least one charter party before an Amsterdam notary on behalf of the shipping company, while the bookkeeper seems to have arranged several private contracts with freighters. ${ }^{28}$ Together, the two men applied for a passport for Vrouw Maria in 1769. ${ }^{29}$ Both their names were also mentioned in the registration of the crew of the vessel before the Amsterdam shipping master in $1770 .{ }^{30}$ But once the ship left harbour, Lourens was in charge.

The decision of merchants to ship goods to St. Petersburg in Vrouw Maria is not difficult to understand. In the late 1760 s Lourens sailed to the Russian port every year. ${ }^{31}$ For example, in 1768 he brought back "sail cloth" for the Amsterdam merchants Martinus and Hendrick Smit. ${ }^{32}$ In 1769 he had been to St. Petersburg to fetch grain for the merchant house Andries Pels and Zoonen,

${ }^{25}$ GAA 5036, Inv. nr. 8, 17 October 1769; and 5071/29 (1766): The back of the deed of sale, stating the price paid, includes the phrase: “Tamme Beth Ysbr. for his Mr. Coenraad Vissering" (my translation).

${ }^{26}$ Hart, "Rederij," 111-112.

${ }^{27}$ In October 1792, Reinhold Lorentzen, from Oland in Denmark, fifty-one years old, living in Amsterdam, married Dorethea Ipsen, forty-five years, also from Oland and living in Amsterdam; GAA, Marriage Register (DTB) 759/417.

${ }^{28}$ In any case Tamme Beth contacted the merchants whose goods were carried in Vrouw Maria after news of the wreckage reached Amsterdam.

${ }^{29}$ GAA 5036/8, 17 October 1769.

${ }^{30}$ GAA 38/2, 9 May 1770 . See also their joint registration in later years of the crew of two other ships; GAA 38/5, 15 August 1772; 38/7, 2 April 1774; 38/10, 4 November 1775; and 38/11, 29 June 1776.

${ }^{31}$ In 1767,1768 and 1769 his name appeared among the masters who paid galjootsgeld on their return from St. Petersburg. In 1769, for example, his seventy-seven last ship and 110-last goederen paid upon his return from St. Petersburg with Vrouw Maria (GAA, PA 6 Inv. nr 60 for galjootsgeld paid by Lourens.)

${ }^{32} \mathrm{GAA}$, NA $12724 / 102,9$ April 1770. 
regular traders with Russia, who were actually among the freighters in $1771 .{ }^{33} \mathrm{It}$ is likely that several other merchants had worked with Lourens previously. In June 1770 Vrouw Maria unloaded prunes and fruit in St. Petersburg for the merchants Brower and Bagge, who would also participate in the next year's shipment. ${ }^{34}$ In any case, after the return of Vrouw Maria from Lisbon in June 1771, word spread that the next destination was St. Petersburg; no fewer than thirty-four merchants chartered part of the ship to carry their goods to Russia. ${ }^{35}$

Since all the ships that sailed to St. Petersburg passed through the Sound, the cargo of Vrouw Maria can be reconstructed from the Sound Toll Registers. The entry of the ship on 23 September 1771 shows that the goods it carried were very typical for Dutch trade with Russia. ${ }^{36}$ The cargo consisted primarily of highvalue commodities such as sugar, dyes, textiles and metals (table 1). In addition, there were small quantities of cod, herring, cheese and butter; some goods belonging to the master and his crew; and an unspecified cargo estimated at 25,000 guilders. ${ }^{37}$ The latter entry may refer to several kinds of commodities. First, the list of goods salvaged from Vrouw Maria in October 1771 mentioned several boxes of coffee, tea, books and tobacco, none of which were noted by customs officials in the Sound. In addition, underwater archaeologists have estimated that at least 1000 clay pipes were on board. ${ }^{38}$ Second, the unspecified cargo may have consisted of ten casks of silver that were shipped in Vrouw Maria by the Amsterdam merchant Lodewijk Hovy. But the description of this bullion shipment in an insurance policy suggests that its value may have been up to twice as high. ${ }^{39}$

${ }^{33}$ GAA, NA 11747/25, 7 April 1769; and Schöffer, "Vonnissen," 103.

${ }^{34}$ Russian Science Academy, Institute of Russian History, St. Petersburg Archive, F. 115 (manuscripts) op. 1, D. 429a. L.10-13 (courtesy of Ismo Malinen of the Finnish Maritime Museum).

${ }^{35} \mathrm{GAA}$, NA 10859/772, 15 July 1771.

${ }^{36}$ Ahlström, Looking for Leads, 159. On the importance of high-value commodities in the Russia trade, see Schöffer, "Vonnis."

${ }^{37}$ The registers of the Sound Toll mention "assorted merchandise" worth 9783 rixdallers; Ahlstrom, "Russian Empress," 14.

${ }^{38}$ Courtesy of Ismo Malinen.

${ }^{39}$ Given that barrels with silver should be light enough to carry but difficult to steal, one might think of a total weight of sixty kilograms, or thirty bars of two kilograms - the weight of bars shipped by the VOC. One would need a silver content of slightly over 
Table 1

Estimated Value of Cargo shipped in Vrouw Maria from Amsterdam to St. Petersburg in 1771

\begin{tabular}{|c|c|c|c|}
\hline Cargo & Quantity & Measure & Value (guilders) \\
\hline Sugar & 85,562 & Pounds & $12,834-28,236$ \\
\hline \multicolumn{4}{|l|}{ Dyes } \\
\hline Madder & 17,980 & Pounds & 3416 \\
\hline Brazilwood & 4700 & Pounds & 987 \\
\hline Indigo & 3230 & Pounds & 17,442 \\
\hline Winestone & 2.33 & Shippounds & 147 \\
\hline \multicolumn{4}{|l|}{ Metals } \\
\hline Mercury & 250 & Pounds & 438 \\
\hline Zinc & 39.75 & Shippounds & \\
\hline Textiles & 728 & Pieces & 32,760 \\
\hline Cotton & 1220 & Pounds & $561-830$ \\
\hline \multicolumn{4}{|l|}{ Foodstuffs } \\
\hline Herring & 0.5 & Barrels & \\
\hline Cod & 0.5 & Barrels & - \\
\hline Butter & 0.75 & Barrels & - \\
\hline Cheese & 0.5 & Shippounds & - \\
\hline Sewing Thread & 2 & Pounds & $<10$ \\
\hline Paper & 20 & Reams & - \\
\hline Clay pipes & $>1000$ & Pieces & - \\
\hline Silver & 10 & Casks & $25,000-55,000$ \\
\hline Paintings Catherina II & 12 & Pieces & 35,288 \\
\hline Paintings Prince Gallitzin & 6 & Pieces & - \\
\hline $\begin{array}{l}\text { Shipmaster's goods } \\
\text { (e.g., cheese, figs, brandy) }\end{array}$ & & & 2763 \\
\hline Total value & & & $130,000-180,000$ \\
\hline
\end{tabular}

Note: Brazilwood was rasped to make red dye.

Source: C. Ahlstrom, "The Russian Empress and the Dutch Kofschip Vrouw Maria," Nautica Fennica (2000), 14; and N.W. Posthumus, Nederlandse Prijsgeschiedenis (2 vols., Leiden, 1943-1964).

900 (which could be reached by melting Spanish piasters) for the bullion to be minted right away in St. Petersburg. These amounts would yield a production of some 55,000 guilders. (Courtesy of Marcel van der Beek, National Mint Museum, Utrecht). Note that the largest number of participants (twenty-three) in any of the insurance policies for cargo in Vrouw Maria was for the casks of silver shipped by Hovy, a fact that supports a high estimate of 55,000 guilders for the value of the ten casks (GAA 3012, 1 November 1771). 
Yet another possibility for the unspecified cargo lies in eleven paintings carried to St. Petersburg by Vrouw Maria for Catherine $\mathrm{II} .^{40}$ On 20 July in Amsterdam, the renowned art collection of Gerrit Braamcamp, a wealthy timber merchant who had died a few months earlier, was sold. ${ }^{41}$ For many years the collection had attracted visitors from the Dutch Republic and abroad, for it contained pieces by some of the most renowned artists, including Brueghel, Douw, Holbein, Potter and Rembrandt. Even before Braamcamp's death descriptions of his holdings had circulated in Europe ${ }^{42}$ Several European royals, including the Russian empress, were attracted by the announcement of the auction in 1771. Catherine II asked Prince Dmitri Alexejevitsch Gallitzin, her ambassador in The Hague, to visit the auction and commission local art dealers to buy the most outstanding pieces on her account. ${ }^{43}$ Indeed, at the auction two local brokers bought a dozen paintings for the empress. In addition, Prince Gallitzin bought one painting on his own account, although this was never shipped to Russia. ${ }^{44}$

The value of the paintings of Catherine II can be deduced from a catalogue of the Braamcamp auction which has survived with the names of the buyers and the prices paid written on it. As it turns out, the empress bought the two most valuable pieces in the collection - a triptych ("Lying-in Chamber") by Gerard Dou and a "Drove of Oxen" by Potter - for 14,000 and 9050 guilders, respectively. Contemporaries considered Dou's painting nothing less than a masterpiece, comparable to Rembrandt's "Nightwatch." ${ }^{45}$ In addition to these two

\footnotetext{
${ }^{40}$ It should be noted that Catherine II, like several other nobles, probably enjoyed exemption from the Sound Toll for goods shipped for personal use; Ahlström, Looking for Leads, 189 and 196-197.

${ }^{41}$ The following is based on C. Bille, De tempel der kunst of het kabinet van den heer Braamcamp (2 vols., Amsterdam, 1961).
}

${ }^{42}$ J.F.L. de Balbian Verster, "De bocht van de Heerengracht," Jaarboek Amstelodamum, XXVII (1930), 195.

${ }^{43}$ Ahlström, Sjunkna skepp, 21.

${ }^{44}$ Among the goods salvaged from Vrouw Maria in October 1771 were one large and five small paintings belonging to Prince Gallitzin (RA Kabinetten, Huvudarkivet Inkomna handlingen Huvudserie, E 1 A 11, vol. 11). Yet at the Braamcamp auction Gallitzin appears only to have bought one painting which was still part of his private collection in 1771; Bille, De tempel, 93.

${ }^{45}$ Peter Hecht, "Gerrit Dou's Braamcamp Triptych Reconsidered: A Skeptical View of its 'Allegorical' Meaning," in Cynthia P. Schneider, William W. Robinson and Alice I. Davies (eds.), Shop Talk: Studies in Honor of Seymour Slive Presented on His 
paintings Catherine II probably bought ten other paintings, nine of which were also shipped in Vrouw Maria. ${ }^{46}$ These pieces, including works by Van Ostade, Van Goyen and Metsu, were worth 12,238 guilders. Thus, the total value of the paintings of Catherine II can be estimated at somewhat over 35,000 guilders.

The value of the other goods in Vrouw Maria can be estimated by combining the entries in the Sound Toll Registers with the prices quoted for these goods on the Amsterdam Exchange. Indeed, in August 1771 prices were listed in the Dutch port for all the dyes carried by Vrouw Maria, as well as for the mercury, cotton and sewing thread in the ship. Together these goods were probably worth around 23,000 guilders. Since the Amsterdam price currents also contained various quotations for refined sugar, we can estimate the sugar carried by Vrouw Maria to be worth between 13,000 and 28,000 guilders.$^{47}$ The cheese, figs, grain, brandy, vinegar and medicine water shipped by Lourens were not specified in the Sound Toll books, but at an auction in Turku in October 1771

Seventy-Fifth Birthday (Cambridge, 1995), 100-104. For a copy of Dou's painting by Willem Joseph Laqui, see R. Baer (ed.), Gerrit Dou 1613-1675. Master Painter in the Age of Rembrandt (The Hague, 2000), 17. I would like to thank Marten Jan Bok of the University of Amsterdam for this reference.

${ }^{46}$ Only the works by Dou and Potter were explicitly referred to in the catalogue as being purchased for the empress. But $\mathrm{C}$. Bille's research into other paintings bought by one of the two brokers for Catherine II has proved that these were never seen again afterwards: "None of the purchases made by Van den Bogaarde at Braamcamp's auction could be traced. It is to be feared that they were all destined for the collection of the Empress of Russia and consequently lost at sea." (Bille, De tempel, 105) The one exception was a painting by Pierre Mignard called "Jephta Meeting His Daugther." According to a catalogue published in 1903, the picture was shipped in another vessel (Bille, De tempel, 107). Meanwhile, there is no proof for the contention that besides the already mentioned works some paintings bought by the Amsterdam Broker Philippus van der Schey at the Braamcamp auction were shipped in Vrouw Maria (Verweij, "Laatste reis," 142; and Bille, De tempel, passim). Even so, it is possible that additional paintings were shipped in the vessel. In a letter to the Chancellor in Stockholm, the Swedish envoy in St. Petersburg, Carl Ribbing, wrote that "at the end of last week came back from Turku [Äbo] the courier of the Russian cabinet, Major Their, who was sent there by Her Royal Majesty to supervise the salvage of various paintings belonging to Her Majesty, the value of which is 50,000 ruble." Considering that at the time each ruble contained eighteen grams of silver, and each guilder 9.7 grams (Courtesy Marcel van der Beek of the National Mint Museum in Utrecht), these paintings would be worth approximately 92,783 guilders - an amount well above the price paid at the Braamcamp auction.

${ }^{47}$ See also the reference to a purchase of thirty-three casks of sugar, worth 12,434 guilders, to be shipped in Vrouw Maria, found in the ledgers of one of the freighters, Hope \& Co; Verweij, “De laatste reis," 138. 
they yielded 2763 guilders.$^{48}$ Unfortunately, we cannot calculate the value of the fish and dairy products in the ship, for the measures mentioned in the Sound Toll Registers do not correspond with those used in Amsterdam. Still, the small amounts make it clear they were not the ship's principal cargoes. This was not the case for the more than 700 pieces of cloth carried to St. Petersburg. Since both the length and quality of these textiles may have varied considerably, we can only roughly estimate their value. If we accept a standard length of sixty ell for all pieces, and an average price of 0.75 guilders per ell, the total value would be 32,760 guilders. ${ }^{49}$ In all, the value of the goods shipped in Vrouw Maria must have been between 130,000 and 180,000 guilders.

On 12 August 1771 dockworkers started to load Vrouw Maria with casks and barrels of sugar, dyestuffs, metals and textiles, along with several crates containing the paintings from the Braamcamp collection. ${ }^{50}$ While loading proceeded over the next three weeks, both shipowners and freighters prepared to protect themselves against possible damages or the loss of the ship and cargo. Even if Baltic trade was safeguarded from piracy and most times from warfare, bad weather (including ice) and navigation posed considerable dangers. ${ }^{51}$ In particular, the final haul to St. Petersburg, skirting the Finnish coast in order to enter the mouth of the River Neva, was notorious for its rocks and cliffs. ${ }^{52} \mathrm{~A}$ recent inventory of shipwrecks in the waters around Finland reveals about fifty strandings of Dutch ships alone in the second half of the eighteenth century. ${ }^{53}$ Indeed, only two months after the wreck of Vrouw Maria another ship carrying

\footnotetext{
${ }^{48}$ Turun Kaupunginarkisto, P I a 17.
}

${ }^{49}$ The estimated price is based on the minimum (0.40) and maximum price $(1.50)$ of linen cloth in the second half of the eighteenth century. I would like to thank Cor Trompetter of Fryske Akademie for this information.

${ }^{50}$ While there is no irrefutable proof of the precise number of Braamcamp paintings carried by Vrouw Maria, it is remarkable that of all the paintings sold to Catherine II's agents, only one has ever been found in a museum or private collection thereafter. This led the art historian Bille, who thoroughly investigated the collection sold at the Braamcamp auction, to believe that all were carried in Vrouw Maria and consequently lost. There is no reason to doubt this assessment (Bille, De tempel).

${ }^{51}$ F.C. Spooner, Risks at Sea. Amsterdam Insurance and Maritime Europe, 17661780 (Cambridge, 1983), 139-142.

${ }^{52}$ Ahlström, Looking for Leads, 158.

${ }^{53}$ Courtesy of Ismo Malinen of the Finnish Maritime Museum. 
"parcelled goods" from Amsterdam to St. Petersburg got into trouble near Turku, though this time it was towed to port for repairs.

The obvious protection against the perils of the sea was an experienced crew and a vessel able to withstand severe weather. As far as the latter was concerned, Vrouw Maria was relatively small, measuring only 140 tons compared to an average tonnage in the Dutch fleet sailing to St. Petersburg of about 190 tons. Still, Lourens was experienced enough to cope with the dangers of the skerries of the Finnish archipelago. ${ }^{54}$ Indeed, he had already made the same voyage with Vrouw Maria several times. A further means for shipowners to protect themselves against possible losses was the partenrederij - the parcelling out of the ownership in shares. A shipowner could also insure the hull of his ship, but this only became common in the nineteenth century. ${ }^{55}$ Whether the ownership of Vrouw Maria was indeed divided among different merchants is difficult to say. A reference to Tamme Beth as one of the reders in 1769 does suggest that others besides Coenraad Vissering participated, but unfortunately there is no proof for this contention.

To spread the risk of losing merchandise in shipwrecks merchants could either use different ships to transport their goods or insure their freight. ${ }^{56}$ In the Russian trade merchants probably combined both strategies. ${ }^{57}$ Cargo shipped to St. Petersburg often included precious metals, works of art and other luxury items, so it would be unwise for merchants to put all their eggs in one basket. ${ }^{58}$ Nonetheless, even after parcellization, the value of merchandise was such that many consigners took out insurance. ${ }^{59}$ In Amsterdam this was easy, since the Dutch port had been Europe's principal insurance market since the late sixteenth

${ }^{54} \mathrm{Knoppers,} \mathrm{"De} \mathrm{vaart} \mathrm{in} \mathrm{Europa,"} \mathrm{226-261.}$

${ }^{55} \mathrm{~V}$. Barbour, "Marine Risks and Insurance in the Seventeenth Century," Journal of Economic and Business History, I (1928-1929), 567-568; F.J.A. Broeze, "Rederij," in Broeze, Bruijn and Gaastra (eds.), Maritieme geschiedenis der Nederlanden, III, 106-112; and Davids, "Zekerheidsregelingen," 184-188.

${ }^{56}$ Davids, "Zekerheidsregelingen," 185.

${ }^{57}$ For example, the account books of the insurance brokers Vos and Zonen reveal hundreds of policies bought by the merchant house of Muilmans and Sons for shipments to the Mediterranean, England and the Baltic, including St. Petersburg; GAA 557/24, 25.

${ }^{58}$ Barbour, "Marine Risks," 570.

${ }^{59}$ Schöffer, "Vonnissen," 105-112. 
century. ${ }^{60}$ In 1771 Amsterdam boasted several dozen insurance brokers who specialized in matching demand for insurance with the supply of capital from local underwriters. ${ }^{61}$ The latter group consisted largely of fellow merchants who put away part of their capital in a large number of insurance policies. ${ }^{62}$ Even though competition from English insurers grew in the second half of the eighteenth century, the supply of capital and the demand for insurance was such that merchants in Amsterdam had no trouble buying insurance for every destination at very low rates. In fact, the years $1765-1775$ marked an all-time low in Dutch insurance rates. It was only in the 1780 s, due to both political crises and superior business organization, that London took over as Europe's principal insurance market. ${ }^{63}$

The insurance on cargo shipped in Vrouw Maria is witness to the strength of the Amsterdam insurance market. Between August 10 and August 30 eleven freighters took out insurance for goods in Vrouw Maria.$^{64}$ Lodewijk Hovy and Co. even signed two policies, one of which specified the previously mentioned casks of silver. Each policy was signed by between three and twentythree merchants. In all there were forty-seven insurers, several of whom participated in more than one policy. ${ }^{65}$ Considering that the total value of freight

${ }^{60}$ Spooner, Risks at Sea, 15-46; and Davids, "Zekerheidsregelingen," 184.

${ }^{61}$ Van Eeghen, "De Vos," 50; and Barbour, "Marine Risks," 596.

${ }^{62}$ Spooner, Risks at Sea, 26-38.

${ }^{63}$ Ibid., 55-60.

${ }^{64}$ Unfortunately, we do not know whether other merchants did not insure their cargo or did so elsewhere. We know that insurers in London, Rotterdam and Middelburg were involved in the trade of Amsterdam merchants (Ibid., 33-47), and since not all freighters shipped great values of merchandise it is conceivable that several who used Vrouw Maria simply decided not to take out any insurance at all (Schöffer, "Vonnissen," 106-112; and Davids, "Zekerheidsregelingen," 183 and 190).

${ }^{65} \mathrm{GAA}$ 3012. The distribution of underwriters in the twelve policies written in Amsterdam was as follows:

$\begin{array}{lcc}\text { Policies } & \text { Underwriters } & \text { Lines Written } \\ 1 & 15 & 15 \\ 2 & 15 & 30 \\ 3 & 12 & 36 \\ 4 & 3 & 12 \\ 5 \text { or more } & 2 & 15 \\ \text { Total } & \mathbf{4 7} & \mathbf{1 0 8}\end{array}$


carried by Vrouw Maria did not exceed 180,000 guilders, the average value of their participation can be estimated at less than 1650 guilders. This meant that even the most active insurer, A. Scharff, who participated in nine different policies, probably risked no more than 15,000 guilders in what would be the last voyage of Vrouw Maria. ${ }^{66}$

On Monday, 2 September 1771, loading was completed and Vrouw Maria was ready to sail for St. Petersburg. ${ }^{67}$ For a few days the vessel had to wait for good winds but on 5 September it left Amsterdam. Once arrived at the roads of Texel another delay of five days was incurred for, as often happened, the wind did not allow departures for the Baltic. It was only on Friday, 13 September, that Vrouw Maria finally set sail to the east. The ship's log written by Lourens revealed a calm voyage until Vrouw Maria hit the rocks near Turku on the evening of 3 October. After a night of continuous pumping it was clear that the vessel was doomed, and Lourens ordered his crew to abandon ship. Together with his men he managed to reach a nearby uninhabited island. Thereafter it was Lourens' duty to salvage as much of the ship and cargo as possible. ${ }^{68}$

The first thing to worry about was the protection of the ship and its cargo against appropriation by the local populace, for it was not unusual for local fishermen and farmers to try to reach a ship, strip its rigging, unload as much of its cargo as possible, and then "negotiate" a princely award. ${ }^{69}$ This was in fact what happened one year later to one of the freighters of Vrouw Maria, the Amsterdam merchant Lodewijck Hovy. After the ship De Liefde, which he owned with various other merchants, had ran aground on the Scottish coast, local inhabitants assisted in bringing ashore a large part of its cargo. But they unloaded the merchandise in such a remote place that recovery proved costly. Shortly after the accident, a local official claimed $£ 300$ expenses from the shipowners for his efforts to save the ship and its cargo. Hovy refused to pay, for he had no share

\footnotetext{
${ }^{66}$ Note that if other merchants took out insurance elsewhere, the risk for the underwriters listed in the twelve known policies may even have been smaller.

${ }^{67}$ Details about the last voyage of Vrouw Maria can be retrieved from the ship's $\log$ which, in Swedish translation, was added to the attestation of Reynoud Lourens before the city council of Åbo on 16 October 1771 . The Swedish text was published by Ahlström, Sjunkna skepp, 21-27; the same author also provided an English translation of the most relevant parts in "Documentary," 66-67.
}

$$
\begin{aligned}
& { }^{68} \text { Hart, "Rederij," 111-112. } \\
& { }^{69} \text { Barbour, “Marine Risks," } 563 .
\end{aligned}
$$


in the cargo and had never asked the official to intervene in the first place. The resulting legal process dragged on until $1775 .^{70}$

In the case of Vrouw Maria such difficulties did not arise because in the early eighteenth century Swedish authorities had created diving and salvage companies to coordinate the rescue work of local fishermen and farmers on the coasts of Sweden and Finland, then under Swedish rule. ${ }^{71}$ The company responsible for the Finnish coast, the Northern Diving and Salvage Company, was subdivided into local sections, one of which was established in Turku. ${ }^{72}$ In exchange for a fee that could be as high as twenty-five percent of the value of the salvaged goods, the inhabitants were expected to assist with the rescue and/or unloading of any ship stranded on the coast. Thus, as soon as the locals learned about the misfortune of Vrouw Maria, they set out to offer their assistance to the master and his crew. On 4 October the ship's log read: "Towards the evening [at] five a boat arrived with five men in it, who promised our captain to come back the next day with as many men as possible."73 Since the ship was still making water and the weather continued to be bad, the help of local fishermen and farmers was more than welcome. On Saturday and Sunday they, together with the crew, tried to pump out as much water as possible. On Monday it was decided to open the forehatch and unload whatever cargo could be taken out. For two days the crew, along with a group of thirty-four locals, salvaged a variety of boxes and casks, some still dry, others already damaged by the water. The salvage operation ended on Wednesday morning, 9 October: "We went to look after our ship, but couldn't see her any more."

The next thing to do was to bring ashore the salvaged cargo and carefully register what had been saved. This was not only in the interest of the shipowners, freighters and insurers in Amsterdam (for whom Lourens noted everything in the ship's log) but also for the local salvage company. ${ }^{74}$ Indeed, shortly after Vrouw Maria disappeared, customs officials from Turku arrived to supervise the transfer of the salvaged goods in a boat that then returned, probably together with the

${ }^{70} \mathrm{GAA}, \mathrm{NA} 6 / 84$, Draft report of Directors of Muscovy Trade to Burgomaster Temminck of Amsterdam, 5 July 1774.

${ }^{7}$ Ahlström, Looking for Leads, 81 and 228-230.

${ }^{72} I$ bid., 163,186 and 193.

${ }^{73}$ Ahlström, "Documentary," 66.

${ }^{74}$ Barbour, “Marine Risks," 582-583. 
crew and its helpers, to the city. ${ }^{75}$ In Turku the local head of the Northern Diving and Salvage Company drew up a list of all the goods retrieved from Vrouw Maria. Officials of Turku's administrative court than commissioned two merchants, two goldsmiths, two academics and a sailmaker to estimate the value of the merchandise. ${ }^{76}$ From these documents it is clear that the sugar, metal, most of the dyestuffs and the empress' paintings had been lost. ${ }^{77}$ Lodewijck Hovy's silver was saved, however, together with quite a few goods belonging to the master. Part of the textiles had been salvaged as well, though the company records do mention water damage. In addition there were several goods - notably tobacco, coffee, tea, bulbs and seeds, books and printed material - that had not been listed in the Sound Toll Registers. ${ }^{78}$

Once the cargo and crew had arrived in Turku, it was essential for both the master and the local authorities to register how the disaster had come to pass. In case of a stranding it was not unusual for the master and his crew to visit a local notary to record the circumstances that led to the accident. ${ }^{79}$ In Turku notaries were not involved in such procedures but Lourens did appear before the city council on 16 October to detail the events. For the occasion the magistrates even commissioned a Swedish translation of the ship's log - the very source that eventually led historians and archaeologists to discover the wreck. ${ }^{80}$ It is not unlikely that Lourens retained the original log to hand over to his shipping company in Amsterdam - most likely with copies of other relevant documents drafted in Turku.

${ }^{75}$ Ahlström, "Russian Empress," 14.

${ }^{76}$ Turun Kaupunginarkisto, A I a 9. Commissioner Carl Gustav Fithie of the Northern Diving and Salvage Company submitted his report at the Turku's Court House on 26 October 1771 and then moved on to complain about the choice of specialists to estimate the value of the salvaged goods.

${ }^{77}$ The loss of the Empress' paintings was confirmed in a letter from Carl Ribbing (the Swedish envoy in St. Petersburg) to Baron Scheffer, the Swedish Chancellor in Stockholm, in October 1771. Courtesy of Ismo Malinen of the Finnish Maritime Museum. 11.

${ }^{78}$ RA Kabinetten, Huvudarkivet Inkomna handlingen Huvudserie, E 1 A 11, vol.

${ }^{79}$ Hart, "Rederij," 112.

${ }^{80}$ Turun Kaupunginarkisto, A I a 9. For a transcript of the ship's log in Swedish, see Ahlström, Sjunkna skepp, 22-27; for an English summary, see Ahlström, "Documentary Research," 66-67. 
Finally, the Northern Diving and Salvage Company had to be compensated. To that effect the company had the power to auction salvaged goods and/or the equipment (sails, rigging, etc.) from a wrecked ship. ${ }^{81}$ For the merchants involved this could be a costly affair. In 1783, for example, Hovy contested in vain the company's auction (and subsequent appropriation of twentyfive percent of the proceeds) of a load of silver salvaged from another ship lost on the Finnish rocks. ${ }^{82}$ In the case of Vrouw Maria Hovy's ten casks of silver probably made it to St. Petersburg, for only the goods belonging to the master were sold publicly in Turku. ${ }^{83}$ All other merchandise was sent to St. Petersburg after the company had reached an agreement with the owners ${ }^{84}$ Indeed, in April 1772 the St. Peterburgische Zeitung announced the auction of "14 Fässer beschädigten Caffe, geborgen aus dem bey Abo [Turku] gestrandeten Schiff des Schiffers Raymond Laurenz." ${ }^{85}$ Unfortunately, it remains unknown how, and how much, the Northern Diving and Salvage Company was paid. One possibility is that Lourens advanced the company's fees from the proceeds of the auction of his own goods, expecting to recover it at a later stage from the ship's freighters. Whatever the exact procedure, in December 1771 Lourens declared to the company's executives in Stockholm that "not only the employees of the Comp[any] in the archipelago and in Turku, but also the Company itself, in various stages, have shown me and my men all help needed, which I hereby confirm." 86

While Lourens saw to the affairs in Turku, news of the wreck reached the shipowners and freighters involved in the final voyage. Catherine II was probably the first to learn of the loss of the ship. In any case, her foreign minister, Count Panin, who himself owned some of the goods shipped in Vrouw Maria, wrote a letter to the Royal Chancellery in Stockholm asking for assistance in retrieving the "crates with valuable paintings belonging to her Imperial Majesty

${ }^{81}$ Ahlström, Looking for Leads, 74.

${ }^{82}$ Ibid., 167.

${ }^{83}$ Turun Kaupunginarkisto, P I a 17.

${ }^{84}$ Stockholm, Krigsarkivet, Amiralitetskollegium, Lotskontoret. E VI 1771-1772 Dykerihandlingar, 23 December 1771 (Courtesy of Ismo Malinen).

${ }^{85}$ St. Petersburgische Zeitung, 17, 20 and 24 April 1772.

${ }^{86}$ Stockholm, Krigsarkivet, Amiralitetskollegium, Lotskontoret. E VI 1771-1772 Dykerihandlinga, 23 December 1771. 
the Empress. ${ }^{87} \mathrm{He}$ also sent an envoy to the governor of the district of Turku in order to "salvage the paintings and take care of transportation thereafter." In a letter carried by the envoy he asked the governor to help him as much as possible ${ }^{88}$ In the meantime, the Swedish ambassador in St. Petersburg had received a request from the Imperial Court to contact whoever could be of any help.

It may have been from Russia that the news of the wreck reached Amsterdam in the last week of October ${ }^{89}$ The Amsterdamsche Courant, a newspaper believed to have had a correspondent in St. Petersburg, received the tidings on 30 October and published them the next day: "The 3rd of this month in the Finnish Scheere the ship of Reynoud Lourens on its way from here to St. Petersburg stranded on the rocks in a flying storm. The ship was filled with water, with the bottom layer, existing of sugar, dissolved. The shipmaster wrote for assistance to Abö." ${ }^{90}$ Ten days later another newspaper specified the losses of Catherine II: "The ship of captain R. Lourisz heading for Petersburg, loaded with various precious Paintings, from the cabinet of late Mr. G. Braamcamp, is lost in the Scheeren, without any of the cargo salvaged." By the time this news was published, Tamme Beth Ysbrants had already informed the shipowner(s) and merchants with goods in Vrouw Maria. Between 30 October and 1 November, the freighters confirmed the loss of the ship before the Amsterdam notary Salomon Dorper, while giving power of attorney to Beth and one of their fellow merchants to "retrieve all possible goods according to custom, to reimburse salvage costs, to settle any possible conflicts, to go to law if necessary, and to do everything necessary in the interest of their principals. " 92 This was very much a formality,

${ }^{87}$ Ahlström, "Russian Empress," 15.

${ }^{88}$ RA Kabinetten, Huvudarkivet Inkomna handlingen Huvudserie, E 1 A 11, vol. 11.

${ }^{89}$ Yet another possibility, put forward by Verweij, "De Laatste reis," 139, was that information reached Amsterdam via Stockholm, Helsingör and Hamburg.

${ }^{90}$ Amsterdamsche Courant, 31 October 1771.

${ }^{91}$ Maandelykse Nederlandsche Mercurius, 10 November 1771.

${ }^{92}$ GAA, NA 10860/1292. 
for customary law required an official document to validate future insurance claims. ${ }^{93}$

Over the next weeks those merchants who had participated in insurance policies on the goods shipped in Vrouw Maria appeared before the Amsterdam Insurance Chamber to give power of attorney, first to the owners of the cargo to retrieve as much of it as possible and settle the accounts with those responsible for its salvage; and second to one or two participants to check the documents of the insured and settle the matter amicably with them. Since the archives reveal no further interference of the Insurance Chamber, the Directorate of Muscovy Trade or any other public institution, it seems as that the matter was settled without any further ado. Some participants will have demanded an abatement for cargo that did reach its final destination. Since all ten casks of silver shipped by Hovy were salvaged from the wreck, his insurers did not have to pay at all. ${ }^{94}$

For those underwriters who did have to pay, the cost was light. Among the insurers of Vrouw Maria were several merchants, like the previously mentioned A. Scharff, for whom marine insurance was a principal business. These specialists could easily cover losses on one policy with profits from another.$^{95}$ Moreover, the damages of Vrouw Maria were not nearly enough to cause any real pain. Take for example the case of Dirk van Vollenhoven, who wrote lines in three policies along with two of his brothers. ${ }^{96}$ In May 1771 he had reached an agreement with 109 creditors to pay off a total debt of no less than 235,000 guilders. ${ }^{97}$ Likewise, it was easy enough for the freighters of Vrouw Maria to carry the loss of their merchandise. Around 1770 the bank transfers of some of the most prominent houses involved in the ship's final voyage amounted

${ }^{93}$ This abandonment was allowed if the ship were unnavigable or lost: J.P. Vergouwen, De geschiedenis der Makelaardij in assurantiën hier te lande tot 1813 (Den Haag, 1945), 44-45. On regulations concerning shipwrecks, see Schöffer, "Vonnissen;" and Spooner, Risks at Sea, 140.

${ }^{94}$ Barbour, "Marine Risks,” 582-583.

${ }^{95}$ Spooner, Risks at Sea, 32.

${ }^{96}$ GAA 5072/905, no. 1516 ; and GAA 5072/906, no. 1600 .

${ }^{97}$ Which is not to say that all insurers were exceptionally wealthy. Gerard Swam, probably identical to "Gd. Swam" who underwrote one policy, reached an agreement with all his creditors in 1775 for debts totalling only 15,650 gulden (GAA 5072/906, no. 1600). 
to several million guilders per year. ${ }^{98}$ Even freighters who had not insured their cargo probably got away with damages of only a few thousand guilders. Even for the shipowners, who had paid 2400 guilders for Vrouw Maria in 1765 and then enjoyed its benefits for at least five years, damages were easy to overcome.

The losses by merchants in Amsterdam stood in stark contrast with Russian efforts to retrieve the paintings of Catherine II from the wreck. The first attempt to salvage these works of art failed in late 1771 when the Gulf of Finland froze. But the Russians were confident that the paintings, packed in chests, could withstand the sea water long enough to render a second attempt worthwhile. ${ }^{99}$ When spring arrived, they again hired local personnel to try to locate the wreck. ${ }^{100}$ These attempts were not about money, for even if the paintings represented a considerable sum - and may not have been insured - the empress purchased many more works of art. For example, one year after the loss of Vrouw Maria Catherine II bought a Persian diamond weighing 779 carats which was shipped from Amsterdam to St. Petersburg, and insured for no less than

${ }^{98}$ Elias, De Vroedschap, $755,800,816,869,886$ and 1061 . While it is true that at least two merchant houses involved in Vrouw Maria liquidated their affairs in 1772 and 1773, Clifford and Sons fell victim to bill speculation, while Andries Pels and Sons voluntarily went out of business to escape the fate of the Clifford house; M.G. Buist, $A t$ Spes non Fracta. Hope \& Co. 1770-1815. Merchant Bankers and Diplomats at Work (Den Haag, 1974), 21. See also J. Jonker and K. Sluyterman, At Home on the World Markets. Dutch International Trading Companies from the 16th Century until the Present (The Hague, 2000), 119-124.

${ }^{99}$ Count Panin wrote to Baron De Rappe that: "Les peintres et les connoisseurs qui se sont fait un étude de tout ce qui interesse cet art, nous tranquilisent assez sur leur conservation, aussi longtems qu'ils son sous l'eau, surtout à une profondeur où il n'y a guere de frottement et de roulir et point de gelée à craindre, mais ce qu'ils apprehendent le plus, c'est qu'au sortir de l'eau ces caisses et ces tableaux tout mouillés ne soient saisis de la gelée, et qu'ils ne soientpar-làtotalement endommagés" (Riksarkivet, Stockholm, Kabinetten Huvudarkinven 1681-1952, E 1 C 4). Whether this assessment of the chances of recovery was correct is difficult to tell. There is little evidence concerning the protection of paintings shipped in early modern Europe. A painting of Watteau from 1720 shows how large framed paintings were transported in wooden chests padded with straw to absorb shocks. Whether extra protection was used to prevent water damage is not known, however. See J.G. von Hohenzollern (ed.), Friedrich der Grosse. Sammler und Maezen (München 1992), 97 (Courtesy Marten Jan Bok of the University of Amsterdam).

${ }^{100}$ Riksarkivet Stockholm, Handel och Sjofart 37, Report on the failed attempts of the Northern Salvage and Diving Company to locate the wreck of Vrouw Maria. 
500,000 guilders. ${ }^{101}$ The attempts to recover the masterpieces of Potter and Dou were no doubt motivated by cultural arguments - and perhaps personal prestige - rather than financial ones.

As we have seen, in the second half of the eighteenth century the Dutch no longer played a leading role in trade with Russia. Especially in St. Petersburg imports and exports were dominated by English merchants. This is not to say that Dutch merchants disappeared completely from the scene. Every year, several dozen ships sailed from Amsterdam to St. Petersburg, while a few merchants even became bankers to the Russian court. The wreck of Vrouw Maria in 1771 is testimony to the undiminished vitality of Dutch trade. On its way to St. Petersburg, the ship carried the luxury commodities and bullion typical in Russian trade. The organization of the shipment, the spreading of risks by the freighters and the actions after the ship was lost all show that commercial institutions in Amsterdam remained as competitive as before.

For almost everybody involved in the last voyage of Vrouw Maria, the loss of the ship proved no more than a minor setback. Tamme Beth went on to work as a broker in Amsterdam. He would only retire from Amsterdam's broker's guild on 29 January $1793 .{ }^{102}$ After Reynoud Lourens had returned from Stockholm in early 1772, he became master of Johanna en Pieter, a ship once again managed by Beth. In August 1772 Lourens again sailed to St. Petersburg. The merchants who shipped their goods in Vrouw Maria continued to trade in Russia. The well-known firm of Hope and Co. even became the principal banker of the Russian empire in the late $1780 \mathrm{~s} .{ }^{103}$ Finally, in the summer of 1772 , even Catherine II accepted that her paintings would forever lie on the bottom of the Finnish Gulf.

${ }^{101}$ L. van Nierop, “Het dagboek van Jacob Bicker Raye 1732-1772," Jaarboek Amstelodamum, XXXII (1935), 233-234.

${ }^{102}$ In 1781 he owned part of the ship St. Demetrio: P.D.J. van Itserson, "Jens Sörensen alias Jan Sijbrandsz., een Deens zeeman in Amsterdamse dienst," Jaarboek Amstelodamum, LXXVI (1984), 115; and GAA 366/1072, fol. 227.

${ }^{103}$ Buist, At Spes non Fracta, 123-154. 